ROCZNIKI PEDAGOGICZNE

Tom 13(49), numer $1-2021$

DOI: https://doi.org/10.18290/rped21131.10

WIESŁAW PARTYKA

\title{
OCHRONKI W KRÓLESTWIE POLSKIM W ŚWIETLE AKT RADY GŁÓWNEJ OPIEKUŃCZEJ (1832-1870)
}

Idea opieki nad ludźmi potrzebującymi wsparcia, w tym również nad dziećmi osieroconymi, opuszczonymi czy zaniedbanymi, była realizowana od wieków przez różne środowiska. Główną rolę w tej działalności aż do końca XVIII wieku odgrywał przede wszystkim Kościół, wspierany przez władze świeckie i osoby prywatne (Surdacki, 1998; 2015). W zdecydowanej większości była to jednak opieka ukierunkowana na sieroty i dzieci porzucone. Na przełomie XVIII i XIX wieku, wraz z rozwojem przemysłu, przemianami społecznymi, demograficznymi i kulturowymi, rosło zapotrzebowanie na pracę kobiet. Pojawił się zatem problem zapewnienia opieki nad dziećmi, które pozostawały bez opieki przez większą część dnia, właśnie ze względu na pracę obojga rodziców. Duża liczba dzieci, pozostawionych bez opieki, narażona była z jednej strony na wiele zagrożeń fizycznych, z drugiej zaś na demoralizację. Stało się to impulsem do szukania skutecznych rozwiązań i organizowania nowych placówek opiekuńczo-wychowawczych, jakimi były ochronki dla dzieci.

Pierwsze ochronki powstały w Anglii w 1816 r. z inicjatywy Roberta Owena. Bardzo szybko instytucje te zaczęły rozpowszechniać się również w innych krajach Europy (m.in. Francja, Niemcy).

W Królestwie Polskim pierwsza tego rodzaju instytucja została otwarta w 1839 r. w Warszawie z inicjatywy Teofila Janikowskiego (Bołdyrew, 2016). Bardzo istotny wkład w powiększenie liczby ochronek miały powstające w XIX wieku towarzystwa dobroczynności, dla których opieka nad dziećmi stanowiła jeden z podstawowych priorytetów (Markiewiczowa, 2002; Kęp-

Dr hab. WieSŁAw PARTYKA - adiunkt w Katedrze Historii Wychowania, Opieki i Pedagogiki Społecznej, Instytut Pedagogiki, Katolicki Uniwersytet Lubelski Jana Pawła II; adres do korespondencji: Al. Racławickie 14, 20-950 Lublin; e-mail: wieslaw.partyka@kul.pl; ORCID: 00000002-5595-2901. 
ski, 1990; 1993). Organizatorami ochronek były również inne organizacje społeczne, zgromadzenia zakonne, gminy wyznaniowe oraz osoby prywatne, m.in. ziemianie (Przegaliński, 2009, s. 226-296). Przez większą część XIX wieku ochronki zakładano głównie w miastach gubernialnych, powiatowych i osadach przemysłowych, jedynie sporadycznie w małych miasteczkach, na wsiach i w prywatnych dobrach.

Ważny wkład w rozwój ochronek dla dzieci w Królestwie Polskim w XIX wieku miała Rada Główna Opiekuńcza Szpitali (dalej: RGO). Powołana została przez Radę Administracyjną Królestwa Polskiego postanowieniem z dnia 16/28 VIII 1832 roku (Dziennik Praw Królestwa Polskiego [dalej: DzPKP], t. XV, s. 9-25), zastępując dotychczasową Radę Główną Dozorczą Szpitali funkcjonującą przy Komisji Rządowej Spraw Wewnętrznych i Policji od 2 XII 1817 roku (DzPKP, t. IV, s. 54-73). RGO, oprócz ochronek, nadzorowała również funkcjonowanie zakładów dla chorych, ubogich, sierot i podrzutków. Istniejące przy komisjach wojewódzkich rady szczegółowe dozorcze zastąpione zostały radami szczegółowymi opiekuńczymi działającymi przy poszczególnych zakładach dobroczynnych. Rady szczegółowe zarządzały majątkiem danego zakładu, decydowały o przyjęciu podopiecznych, zawierały umowy na dostawy leków i żywności, przygotowywały projekty budżetów i sprawozdania roczne zatwierdzane przez RGO. W 1842 r. wydany został ukaz carski dotyczący działalności RGO i podległych jej placówek pomocy społecznej (DzPKP, t. XXX, s. 4-89). Ukaz ten dawał RGO m.in. władzę zwierzchnią nad instytucjami dla głuchoniemych i niewidomych, salami schronienia (ochrony) dla małych dzieci ubogich rodziców, domami dla włóczęgów i żebraków zdolnych do pracy, domami dla sierot i dzieci zaniedbanych wychowawczo oraz domami poprawy dla prostytutek, które chciały zerwać z dotychczasowym trybem życia. Dotyczyło to wszystkich placówek, bez względu na podmiot założycielski czy prowadzący (Kościół, gminy wyznaniowe, organizacje społeczne, osoby prywatne). Również towarzystwa dobroczynności, mimo swojej autonomii, były zobowiązane do składania sprawozdań ze swojej działalności do RGO. Na mocy ukazu z dnia 19/31 V 1870 r. Rada Główna Opiekuńcza i rady szczegółowe zostały zawieszone, a wszystkie zakłady dobroczynne przeszły pod zarząd Ministerstwa Spraw Wewnętrznych w Petersburgu (DzPKP, t. LXX, s. 189 n.).

Akta centrali RGO, które przed II wojną światową znajdowały się w zbiorach Archiwum Akt Dawnych, spłonęły całkowicie w 1944 r. Obecnie zespół RGO przechowywany w Archiwum Głównym Akt Dawnych w Warszawie tworzą ocalałe akta własne RGO i akta rad szczegółowych opiekuńczych 
przejęte po II wojnie światowej z archiwów terenowych, m.in. Radomia i Kielc. W zespole tym wyróżniony jest dział obejmujący akta sal ochron dla dzieci, głównie z terenu guberni radomskiej (Archiwum Główne Akt Dawnych (dalej: AGAD), RGO, 224, sygn. 60-73). Mimo bardzo skromnego zasobu, liczącego 15 j.a., zawierającego przede wszystkim dane dotyczące administracji i funduszów, analiza materiału źródłowego pozwoliła na uzyskanie bardzo ciekawych informacji i dała podstawy do poniższych rozważań.

RGO starając się zorganizować sieć ochronek w Królestwie Polskim, $\mathrm{z}$ jednej strony zachęcała do takiej działalności potencjalnych opiekunów i donatorów, wspierając wszelkie inicjatywy zmierzające do założenia sali ochrony, z drugiej zaś próbowała wprowadzić pewne standardy w zakładaniu i funkcjonowaniu tych instytucji. Kiedy w 1862 r. zarządca dóbr Deszno w okręgu jędrzejowskim, powiecie kieleckim, wystąpił do Rady Opiekuńczej Zakładów Dobroczynnych Powiatu Kieleckiego w imieniu właścicielki tychże dóbr, Mieroszewskiej, z projektem założenia ochronki, pismo to zostało przesłane do RGO, aby ta podjęła stosowną decyzję (AGAD, RGO, sygn. 60, s. 1). W odpowiedzi RGO pochwaliła sam zamysł utworzenia takiej instytucji i zobowiązała się do wsparcia ze swojej strony, z drugiej zleciła Radzie Opiekuńczej Powiatu Kieleckiego, aby ta dostarczyła Pani Mieroszewskiej pisma dotyczące sal ochrony:

- Rozporządzenie RGO o salach ochrony z 1857 r. zamieszczone w 2 tomie Zbioru urządzeń szpitalnych;

- pismo Augusta Cieszkowskiego „O ochronach wiejskich”.

Ponadto Rada miała uzyskać bliższe informacje dotyczące: zamiarów założycielki, środków jakimi sala ochrony ma rozporządzać w przyszłości, lokalizacji ochrony, opiekunki. Ważną kwestią dla RGO było zabezpieczenie bytu ochrony na przyszłość, w związku z tym zalecała, aby zadbać o sporządzenie przez Mieroszewską stosownego aktu darowizny. Projektowana instytucja miała pozostawać pod zarządem miejscowego dozoru parafialnego, miała posiadać ściśle określony etat oraz składać Radzie powiatowej roczne sprawozdania ze swojej działalności (tamże, s. 1v-2). W tym jednym piśmie zawarty został cały wykaz składowych istotnych z punktu widzenia RGO, aby placówka opiekuńcza, jaką była ochrona, mogła w miarę stabilnie funkcjonować. Polecenie, aby przekazać pani Mieroszewskiej pisma dotyczące sal ochrony, wskazuje, że zamiarem RGO była swego rodzaju unifikacja ochron. Starano się wypracować pewien model placówki opiekuńczej, bazując na dostępnych materiałach. Jednym z podstawowych źródeł, wykorzystywanym w tym celu, była praca A. Cieszkowskiego, którego niewątpliwie 
należy uznać za twórcę rodzimej koncepcji ochron wiejskich (Cieszkowski, 1845). Jego koncepcję zweryfikował i zrealizował w praktyce m.in. E. Bojanowski, tworząc swój autorski system wychowania w ochronkach (Opiela, 2019, s. 8).

Analizując dokumentację RGO, można wyodrębnić kilka istotnych zagadnień, do których przykładano sporą uwagę. Po pierwsze RGO interesowała się tym, gdzie projektowana ochrona będzie zlokalizowana. Nie istniały w tym zakresie żadne szczegółowe przepisy, ważne jednak było, aby - jak to ujął Cieszkowski w swojej pracy - ,[...] była czystą, umiarkowanie ciepłą, łatwo przewietrzalną, suchą, widną i wesołą[...]" i mogła być zlokalizowana zarówno w zabudowaniach folwarcznych lub w jakiejś pustej chacie we wsi (Cieszkowski, 1845, s. 30, 32). Bardzo ważnym zagadnieniem były podstawy materialne funkcjonowania ochrony. Ochrony, podobnie zresztą jak szpitale i domy schronienia, w XIX wieku musiały bazować przede wszystkim na dobroczynności publicznej i filantropach (Partyka, 2017, s. 103-116). RGO starała się niejako wymusić na fundatorach, aby ci stosownymi aktami zabezpieczyli dochody ochrony na przyszłość. Taki zapis w testamencie z 1855 roku uczynił m.in. leśniczy Zenon Krassowski dla ochrony w dobrach Grzmiąca, zobowiązując się przeznaczać rocznie na potrzeby placówki 600 rubli srebrem [rs] (AGAD, RGO, sygn. 61, s. 1-2). Niestałym źródłem dochodu były różnego rodzaju składki i imprezy dobroczynne. Przykładowo w 1865 roku na potrzeby sali ochrony w Sandomierzu z loterii fantowej zebrano 625 rs i 18 kopiejek (AGAD, RGO, sygn. 70, s. 1). Obok zaangażowania indywidualnych darczyńców w finansowe wspieranie ochron, pewną rolę odgrywały również instytucje państwowe. Rząd za pośrednictwem RGO wypłacał zasiłki przeznaczone albo na utworzenie ochron, albo na wsparcie już istniejących. W 1865 r. Komisja Rządowa Spraw Wewnętrznych i Duchownych przeznaczyła na utrzymanie sal ochrony w Królestwie sumę 5000 rs, z czego część miała służyć jako wsparcie na urządzenie nowych ochron (AGAD, RGO, sygn. 65, s. 4). Po 150 rs przeznaczono na utworzenie ochron w Miechowie i Olkuszu, a po 100 rs na utworzenie ochron w Opocznie i Stopnicy (tamże, s. 2; AGAD, RGO, sygn. 66, s. 3; AGAD, RGO, sygn. 67, s. 1; AGAD, RGO, sygn. 71, s. 1). Zasiłki te wypłacane były regularnie, chociaż czasami zmianie ulegała wypłacana suma. Przykładowo na założenie ochrony w Olkuszu w 1865 i 1866 wpłynęło po 150 rs, a w 1867 i 1868 po 120 rs (AGAD, RGO, sygn. 66, s. 1-7).

Bardzo ważną, chociaż nie do końca uregulowaną, była kwestia opiekunki lub opiekunek mających sprawować nadzór nad placówką i jej podopiecz- 
nymi. Pierwsze podręczniki dla ochroniarek w języku polskim zaczęły się pojawiać od lat 40. XIX wieku i były to przekłady i przeróbki dzieł obcych (Jakubiak, 2015, s. 110). Cieszkowski w swojej pracy zamieścił sporo uwag na temat odpowiedniego przygotowania personelu do ochronek. Uważał, że kształcenie „zdatnych przewodniczek” jest bardzo ważne i powinno się odbywać w ramach kilkumiesięcznej praktyki w ochronce miejskiej (najlepiej w stolicy), co przyniesie lepszy efekt, niż nawet kilkuletnie, naukowe i teoretyczne przygotowanie (Cieszkowski, 1845, s. 29). Przy braku wykwalifikowanej kadry, Cieszkowski uważał, że najważniejsze są cechy charakteru, osobiste umiejętności i predyspozycje potencjalnej ochroniarki. Dopuszczał nawet do tej roli kobiety nie potrafiące czytać i pisać (tamże, s. 39-40). Podobnego zdania był również Ludwik Górski, który w pracy z 1899 roku, dotyczącej ochronek wiejskich stwierdził, że „dozorczynią może być kobieta prosta, ale religijna, roztropna i mająca zamiłowanie do dzieci. Nie ma potrzeby wymagać od niej kwalifikacji naukowej nad tę, jakiej potrzeba aby dzieci pacierza dobrze nauczyć i do robót ręcznych powoli wprawiać" (Górski, 1889, s. 16).

RGO starała się uzyskać wszelkie informacje na temat potencjalnej opiekunki, zanim powierzyła jej troskę o ochronkę i dzieci. Czasami opiekunki były wyznaczane bezpośrednio przez fundatorów ochronek. Tak było m.in. w dobrach Grzmiąca, gdzie fundator Zenon Krassowski w testamencie na jedyną opiekunkę dla 12 dzieci wyznaczył swoją żonę. Wdowa po Krassowskim pobierała roczną pensję w wysokości 616 zł i opiekowała się dziećmi, ucząc je również czytać. Według raportu Kornaszewskiego, członka Rady Opiekuńczej Powiatu Radomskiego z 1866 roku, ochrona była prowadzona w sposób bardzo dobry, posiadała odpowiednie zabezpieczenie finansowe, budynek był w niezłym stanie a dzieci były dobrze utrzymane i porządnie ubrane (AGAD, RGO, sygn. 61, s. 8-9). Z kolei w ochronie w Radomiu, z upoważnienia Rady Opiekuńczej Zakładów Dobroczynnych Powiatu Radomskiego, opiekę nad dziećmi sprawowała, bez pobierania wynagrodzenia, uboga wdowa, Tekla Łubieńska, podopieczna radomskiego domu schronienia (AGAD, RGO, sygn. 69, s. 2-4).

Nie wszyscy jednak mieli do końca jasne intencje próbując założyć ochronkę dla dzieci. Dobitnie pokazuje to sprawa ochrony w Mariampolu w guberni augustowskiej. W maju 1856 roku niejaka Agata Topczewska zwróciła się z prośbą do Księcia Namiestnika Królestwa Polskiego o wydanie jej pozwolenia na założenie domu przytułku (ochrony) dla 12 dzieci w Mariampolu, prosząc jednocześnie o udzielenie jej wsparcia ze strony rządu polegającego 
na bezpłatnym udostępnieniu lokalu, w którym miała znajdować się projektowana instytucja oraz dostarczenie jej drzewa opałowego. Aby uwiarygodnić swoją osobę podawała się raz za siostrę miłosierdzia raz za siostrę dominikankę, która wcześniej pracowała w przytułku i ochronce dla sierot w Sulejowie w guberni radomskiej. Ze swojej strony zobowiązała się również do tego, że oprócz zapewnienia dzieciom opieki będzie im również „dawać nauki” (AGAD, RGO, sygn. 65, s. 1-1v). Wydział Wyznań wysłał pismo do gubernatora guberni augustowskiej, aby ten sprawdził prawdziwość informacji przekazanych przez Topczewską. Ten zwrócił się do swojego odpowiednika $\mathrm{w}$ guberni radomskiej z prośbą o zbadanie sprawy i sprawdzenie wiarygodności wszystkich podanych w piśmie informacji. W czasie gdy toczyło się postępowanie sprawdzające, Topczewska nie czekała biernie, lecz wystąpiła z tą samą prośbą bezpośrednio do RGO (tamże, s. 2v). RGO, nie posiadając żadnych wiarygodnych informacji na temat tej kobiety, odmówiła jej prośbie, nie wyrażając zgody ani na przeprowadzenie publicznej zbiórki pieniędzy, ani na powierzenie jej kierownictwa projektowaną instytucją (tamże). Nie wstrzymało to jednak postępowania sprawdzającego wszczętego przez gubernatora, polegającego między innymi na przesłuchaniu świadków. W jego toku na jaw wyszło wiele nieścisłości. Konsystorz Generalny Diecezji Sandomierskiej poinformował, że w diecezji nie ma w ogóle zakonu dominikanek, a sama Topczewska nikomu nie jest znana (tamże). W piśmie do Namiestnika Topczewska informowała, że jest już zakonnicą 14 lat, jednak przedstawiła jedynie patent z 10 II 1855 r. na zakonnicę zakonu św. Dominika trzeciej reguły, wystawiony przez księdza Innocentego Szeliga, prowincjała Zakonu Kaznodziejskiego (tamże, s. 1v, 6v-7). Wynika więc z tego, że była jedynie tercjarką a nie zakonnicą i nie od lat 14 a dopiero od roku. Jednym z ważniejszych dowodów było zeznanie Klary Ziemkowskiej, przełożonej domu ochrony w Sulejowie. Poinformowała, że Topczewska nigdy nie była zakonnicą, a tym bardziej dominikanką, bo takiego zakonu w Sulejowie nie było. Następnie odniosła się do pracy Topczewskiej w sulejowskim instytucie. Okazało się, że przebywała tam jedynie kilka dni i nawet nie dała się bliżej poznać (tamże, s. 2). Być może tych kilka dni wystarczyło, aby Topczewska podjęła decyzję o próbie zorganizowania ochrony w innym miejscu, którą będzie mogła zarządzać i która da jej dach nad głową i utrzymanie. W toku dalszych poszukiwań okazało się, że Topczewska najprawdopodobniej nie potrafi pisać, bo nigdy nie chciała się samodzielnie podpisać, tłumacząc się różnymi dolegliwościami ręki, a przecież chciała uczyć dzieci (tamże, s. 7). Biorąc pod uwagę wszystkie uzyskane informacje Komisja 
Wydziału Wyznań uznała, że Topczewska kierowała się nie tyle troskliwością o los ubogich dzieci, lecz przede wszystkim swoim własnym interesem i zdecydowała nie tylko o udzieleniu odmowy wobec wystosowanej przez nią prośby, dodatkowo zabroniła jej na przyszłość kierować do władz jakiekolwiek prośby podparte fałszywymi danymi (tamże, s. 7-7v).

RGO do końca swojej działalności starała się rozwijać i propagować różne formy opieki zarówno nad dziećmi, jak również nad osobami starszymi. Filantropi, działający w ramach RGO, starali się dokładać wszelkich starań, aby powstające placówki opiekuńcze były prowadzone we właściwy sposób. Niewątpliwie zniszczenie większości akt RGO w czasie II wojny światowej, z badawczego punktu widzenia jest ogromną stratą, jednak analizując ocalałe akta, można stwierdzić, że w ciągu 38 lat funkcjonowania RGO wypracowano solidne podstawy, teoretyczne i praktyczne, pozwalające na masowe powstawanie ochron dla dzieci na przełomie XIX i XX wieku. O ile w latach 60. XIX w. na terenie Królestwa Polskiego funkcjonowało około $18 \mathrm{sal}$ ochrony dla sierot i dzieci ubogich rodziców (z czego 11 podlegało Warszawskiemu Towarzystwu Dobroczynności a 2 Lubelskiemu Towarzystwu Dobroczynności) (Zdanie sprawy z działań szpitali, 1862, s. 68-70), to już na początku XX wieku w samej guberni lubelskiej funkcjonowało ponad sto takich instytucji. W latach 1904-1907 założono ich aż 119 (Szewczuk, 2004, s. 44-45). Można w tym miejscu zadać sobie pytanie, czy było to pokłosiem wcześniejszej działalności RGO, czy wynikało na przykład ze zmiany stosunków społeczno-gospodarczych i większej troski o dzieci, szczególnie zaniedbane i opuszczone. Bez względu na odpowiedź, należy pamiętać o zasługach, jakie włożyła RGO w rozwój opieki nad potrzebującymi na terenie Królestwa Polskiego w latach 1832-1870.

\section{BIBLIOGRAFIA}

AGAD, RGO, Akta administracji funduszów Sali Ochrony w Grzmiacy, sygn. 61.

AGAD, RGO, Akta administracji funduszów sali ochrony w Miechowie, sygn. 65.

AGAD, RGO, Akta administracji funduszów sali ochrony w Olkuszu, sygn. 66.

AGAD, RGO, Akta administracji funduszów sali ochrony w Opocznie, sygn. 67.

AGAD, RGO, Akta administracji funduszów sali ochrony w Sandomierzu, sygn. 70.

AGAD, RGO, Akta administracji funduszów Sali Ochrony w Stopnicy, sygn. 71.

AGAD, RGO, Akta administracji funduszów sali ochrony we wsi Deszno, sygn. 60.

AGAD, RGO, Akta osobiste sali ochrony w Radomiu, sygn. 69.

AGAD, RGO, Akta Sali ochrony w Maryampolu, sygn. 64. 
BoŁDYREW, A. (2016). Źródła do badań nad ochronkami jako instytucjami opiekuńczo-wychowawczymi w Królestwie Polskim w XIX i na początku XX wieku. Studia Paedagogica Ignatiana, 2, 271-289.

CieszKowski, A. (1845). O ochronach wiejskich. Lwów.

Dziennik Praw Królestwa Polskiego, t. IV, s. 54-73.

Dziennik Praw Królestwa Polskiego, t. LXX, s. 189 n.

Dziennik Praw Królestwa Polskiego, t. XV, s. 9-25.

Dziennik Praw Królestwa Polskiego, t. XXX, s. 4-89.

GóRSKI, L. (1889). Ochronki wiejskie. Warszawa.

JAKUBIAK, K. (2015). Początki polskiej pedagogiki przedszkolnej. Edukacja Elementarna, 4, 109-118.

KĘPSKI, C. (1990). Lubelskie Towarzystwo Dobroczynności (1815-1952). Lublin: Wydawnictwo KUL.

KĘPSKI, C. (1993). Towarzystwa dobroczynności w Królestwie Polskim (1815-1914). Lublin: Wydawnictwo UMCS.

MARKIEwiczowa, H. (2002). Działalność opiekuńczo-wychowawcza Warszawskiego Towarzystwa Dobroczynności 1814-1914. Warszawa: Wydawnictwo Akademii Pedagogiki Specjalnej.

OpIEla, M. (2019). Osoba i rodzina wobec wyzwań cywilizacyjnych. Pedagogika integralnego rozwoju i edukacji w koncepcji ochrony Edmunda Bojanowskiego. Lublin: Wydawnictwo KUL.

PARTYKA, W. (2017). Opieka instytucjonalna na Lubelszczyźnie w XIX wieku. Szpitale i przytułki. Lublin: Towarzystwo Naukowe KUL.

PRZEgaliński, A. (2009). Społeczna działalność ziemiaństwa lubelskiego w latach 1864-1914. Lublin: „Werset”.

SuRdacki, M. (1998). Dzieci porzucone w Szpitalu Świętego Ducha w Rzymie w XVIII wieku. Lublin: Towarzystwo Naukowe KUL.

Surdacki, M. (2015). Opieka społeczna w Polsce do końca XVIII wieku. Lublin: Towarzystwo Naukowe KUL.

SzEWCZUK, D. (2004). Ochronki w guberni lubelskiej w latach 1853-1914. Res Historica, 18, 43-55.

Zdanie sprawy z działań szpitali i instytutów dobroczynnych $w$ Królestwie Polskim za rok 1861, (1862). Warszawa.

\section{OCHRONKI W KRÓLESTWIE POLSKIM W ŚWIETLE AKT RADY GŁÓWNEJ OPIEKUŃCZEJ (1832-1870)}

\section{STRESZCZENIE}

Głównym celem artykułu jest próba ukazania wkładu Rady Głównej Opiekuńczej (18321870) w organizację ochron dla dzieci na terenie Królestwa Polskiego w XIX wieku. Z powodu zniszczenia większości akt RGO w czasie II wojny światowej badania oparte są jedynie na szczątkowym zespole znajdującym się w zbiorach Archiwum Głównego Akt Dawnych w Warszawie. $Z$ zachowanych akt wynika, że RGO starała się nadzorować działalność ochron w Królestwie Polskim i mobilizowała lokalnych filantropów do zakładania nowych. Dbała przy tym o zachowanie pewnych standardów co do lokalu czy zabezpieczenia finansowego planowanej ochrony. Dużą wagę RGO przykładała do tego, aby funkcje opiekunów powierzano osobom godnym zaufania, których celem było przede wszystkim dobro dzieci. Wszelkie nadużycia starano 
się eliminować. W latach 60. XIX wieku na terenie Królestwa Polskiego funkcjonowało kilkanaście ochron dla dzieci, natomiast na masową skalę zaczęły one powstawać na początku XX wieku. $\mathrm{Z}$ pewnością spore zasługi w tym zakresie miała RGO, która przygotowała wcześniej grunt pod tego typu działalność.

Słowa kluczowe: Rada Główna Opiekuńcza; ochronki; Królestwo Polskie; XIX wiek.

\section{CHILD WELFARE CENTRES IN THE POLISH KINGDOM IN LIGHT OF THE RECORDS KEPT BY THE CENTRAL WELFARE COUNCIL (1832-1870)}

\section{SUMMARY}

The main aim of the article is to show the contribution of the Central Welfare Council (18321870 ) to the organization of protection for children in the Polish Kingdom in the $19^{\text {th }}$ century. Due to the destruction of the majority of the Council's files during the Second World War, the research is based only on the residual team found in the collection of the Main Archive of Old Files in Warsaw. The preserved records show that the CWC tried to supervise the protection activities in the Kingdom of Poland and mobilized local philanthropists to establish new ones. At the same time, it took care to maintain certain standards as to the premises and financial security of the planned protection. The $\mathrm{CWC}$ attached great importance to the fact that the functions of guardians were entrusted to trustworthy people, whose primary goal was the welfare of children. All abuses were eliminated. In the 1860 s, in the Kingdom of Poland, there were several dozen or so guardianships for children, while on a mass scale they started to be established at the beginning of the $20^{\text {th }}$ century. The CWC, which had previously prepared the ground for this type of activity, certainly had considerable merit in this respect.

Keywords: Central Welfare Council; protections; Kingdom of Poland; XIX century. 